\title{
Sustainability of Kampung Jawi as Tourist Destination in Semarang City During Covid-19 Pandemic
}

\author{
Rina Kurniati ${ }^{*}{ }^{*}$, Bella Shifa $^{2}$, and Nurini ${ }^{1}$ \\ ${ }^{1}$ Urban and Regional Planning, Diponegoro University, Semarang, Indonesia \\ ${ }^{2}$ Urban and Regional Planning, Diponegoro University, Semarang, Indonesia
}

\begin{abstract}
Kampung Jawi is one of the cultural tourism destinations in Semarang City. Kampung Jawi was developed to reduce poverty and support sustainable development. However, the sustainability of Kampung Jawi as a tourist destination is currently being threatened by the Covid-19 pandemic. The Covid-19 pandemic caused a decrease in the number of tourists and restrictions on activities in the tourism sector, including economic and sociocultural activities. This study aims to examine the sustainability of Kampung Jawi as a tourist destination during the Covid-19 pandemic. The sustainability assessment uses indicators based on 3 aspects: socio-cultural, economic, and environmental. This study uses a quantitative method with descriptive and scoring analysis. Descriptive analysis was used to identify the condition of Kampung Jawi tourism components. The assessment of the sustainability of Kampung Jawi as a tourist destination used a scoring analysis. The result of this study shows that the level of sustainability of Kampung Jawi is included in the "Medium" category. The socio-cultural aspect is the most affected aspect by the Covid-19 pandemic and has the lowest score compared to other aspects. Nevertheless, in the pandemic situation, Kampung Jawi still provides economic benefits, cultural preservation, and maintain environmental purity.
\end{abstract}

\section{Introduction}

Sustainable development is a development concept that emphasizes the balance of economic, ecological or environmental, and social aspects [1]. Tourism and sustainable development are complimentary things. Tourism is considered a sustainable development strategy that can ensure the welfare of the current community and future generations. Tourism is also the right strategy to directly involve the community in the sustainable development process. Semarang City Government is intensively developing tourism with a community-based tourism approach. Community-based tourism development in Semarang City is supported by the Thematic Village program which began in 2016. Kampung Jawi, which is located in Sukorejo Village, Gunungpati District, is an example of a thematic village that has succeeded in developing into a tourist village. A tourism village is a form of integration between

*Corresponding author: rina.kurniati@pwk.undip.ac.id 
attractions, accommodation, and supporting facilities, which are presented in the order of people's lives so that it becomes attractive tourism [2]. Kampung Jawi as a tourist destination has an attraction in the form of Javanese traditional arts and culture that are still preserved. In addition, the social life of the community that still upholds kinship, cooperation, and warm hospitality is also potential support for tourism in Kampung Jawi. The development of Kampung Jawi as a tourism village aims to realize sustainable development from economic, socio-cultural, and environmental aspects.

However, the sustainability of Kampung Jawi as a tourist destination is currently faced with several challenges due to the Covid-19 pandemic. The government has implemented a large-scale social restriction policy to prevent the spread of the Covid-19 virus. This policy had an impact on social and economic activities, especially in Semarang City. The tourism sector, which is one of the driving forces for the regional economy of Semarang City, is under pressure. Based on data from the Semarang City Government [3], in 2020 the number of domestic and foreign tourists in Semarang City has decreased drastically. In 2019 there were $7,223,529$ domestic tourists but in 2020 it decreased to 2,063,574 tourists [3]. Meanwhile, the number of foreign tourists in 2019 was 82,032 tourists but in 2020 it has decreased to 5,501 tourists [3]. The reduced number of tourists causes economic losses to the tourism sector. People who depend their economy on the tourism sector lose their jobs or their incomes are decreased. This condition also occurred in Kampung Jawi where the number of tourist visits decreased and caused a decrease in people's income.

On the other hand, cultural preservation activities that were originally integrated into the tour package were stopped. During normal conditions, there are 11 cultural tourism attractions, but during a pandemic condition, only 1 attraction will be maintained. Social activities of the community that support tourism activities such as community forums are also restricted. This condition could threaten the socio-cultural sustainability in Kampung Jawi. The sustainability of Kampung Jawi as a tourist destination during the Covid-19 pandemic needs to be supported by new normal facilities and infrastructure. Currently, the facilities that support tourism and new normal habits in Kampung Jawi are still being developed. Based on the conditions of Kampung Jawi, which is faced with various challenges, further research is needed. Assessments related to sustainability based on economic, socio-cultural, and environmental aspects are urgently needed. Therefore, this research was conducted to assess the level of sustainability of Kampung Jawi as a tourist destination during the Covid-19 pandemic in terms of three aspects of sustainability.

\section{Theories}

\subsection{Tourism Village}

According to [4], a tourism village is a combination of attractions, accommodation, and accessibility shown in a social structure. A tourism village is an integration of attractions, accommodation, and supporting facilities that is presented in an order of community life that is united in the prevailing ways and tradition [5]. It can be concluded that the tourism village is a combination of attractions, accommodation, and supporting infrastructure that are integrated into people's lives and packaged in a tour.

\subsection{Tourism Components}


A location that is developed into a tourist destination must be able to fulfill and provide tourism components. According to Isdarmanto [6], the tourism components consist of attractions, tourist facilities and services (amenities), accessibility, and ancillary services.

- Attraction, there are 2 types of tourist attractions, namely natural tourist attractions (sourced from nature such as mountains, beaches, waterfalls, etc.) and man-made tourist attractions (in the form of cultural tourism and human creation).

- Amenities, the availability of supporting facilities and infrastructure that tourists needed, starting from departing from home, while in tourist destinations, and returning home. Facilities that can be provided at a tourist spot include accommodation, transportation, restaurants, health centers, public toilets, parking areas, and travel.

- Accessibility, how tourists can reach the destinations easily. Accessibility is supported by the availability of facilities and infrastructure to get to the destination. The support facilities that need to be provided include transportation and road signs.

- Ancillary Service, an institution or organization that manages and administers a tourism destination. Ancillary is a component that plays an important role in regulating other tourism components (attractions, supporting facilities, and accessibility).

\subsection{Sustainability Aspects}

Sustainable tourism is tourism with a development concept that responds to the needs of the current generation without reducing the capacity of next-generation and does not have a negative impact on the environment, economy, and culture of local communities [7]. Three important aspects that must be considered in realizing tourism sustainability are economic, socio-cultural, and environmental aspects.

- On the economic aspect, sustainable tourism must be able to provide optimal long-term economic benefits, especially for the surrounding community. To assess the sustainability of a tourist destination from an economic aspect, three factors are considered: quality of work, economic viability, and local prosperity [8].

- On the socio-cultural aspect, Sustainable tourism aims to maintain and respect the cultural heritage that exists in a tourist destination. To assess the sustainability of a tourist destination from a socio-cultural aspect, five factors are considered: social equity, visitor fulfillment, local control, community wellbeing, and cultural richness [8].

- On the environmental aspect, sustainable tourism must be able to avoid all negative impacts on nature, the environment, and ecosystems that may arise from tourism activities. To assess the sustainability of a tourist destination from an environmental aspect, four factors are considered: physical integrity, resource efficiency, and environmental purity [8].

\subsection{Kampung Jawi as Study Area}

Kampung Jawi is administratively located in Sukorejo Village, Gunungpati District, Semarang City. The total population of Kampung Jawi in 2021 is 1.628 people. Kampung Jawi covers the entire hamlet 01 area and consists of 7 neighborhood associations. Each neighborhood association is connected by the main road, Jalan Kalialang Lama. Kampung Jawi is traversed by a river, namely the Kripik River. The existing territorial boundaries of Kampung Jawi are illustrated in Figure 1. 


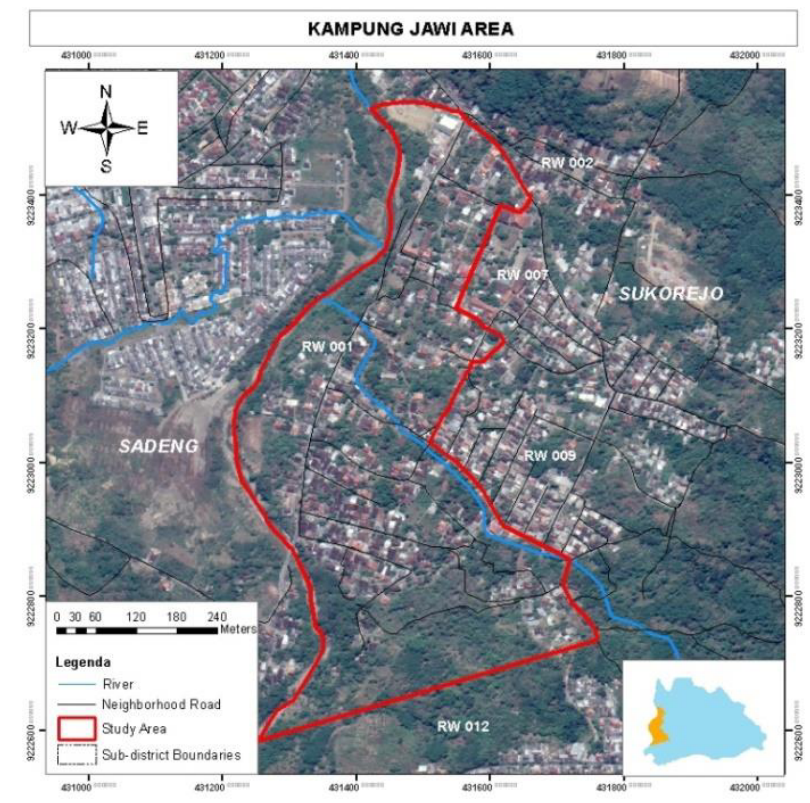

Fig.1. Kampung Jawi Area.

Kampung Jawi is a thematic village with the theme of a cultural tourism village in the city of Semarang. Semarang City Government held a thematic village program to alleviate poverty, address the problem of slum settlements, and develop local potential [9]. Kampung Jawi was designated as a thematic village in 2016, then developed into a cultural tourism village. There are various arts and cultures that are preserved such as traditional dances, karawitan, traditional toys, traditional food, traditional, batik art, and others. That arts and culture are also part of the tourist attractions of Kampung Jawi.

\section{Research Method}

This research used a quantitative method approach. The sample in this study was the Kampung Jawi community with a total of 94 respondents obtained from the calculation of the Slovin formula. Data analysis in this study used descriptive analysis and scoring analysis techniques. The sustainability value is obtained from the results of a questionnaire given to the Kampung Jawi community as respondents. The scale used in this scoring analysis is the Likert Scale. The Likert Scale is used to measure opinions, attitudes, and perceptions of a person or group about a phenomenon [10]. Respondents assessed the sustainability of Kampung Jawi based on economic, socio-culture, and environmental aspects. Each aspect has variables and indicators which are represented by a list of questions. Each question has 3 answer choices which are converted into a score of 1 to 3 . If the economic, socio-cultural, and environmental conditions are considered to be able to support the sustainability of Kampung Jawi, then the score will be higher. Table 1 shows the variables and indicators of Kampung Jawi's sustainability as a tourist destination that adapted from Asmelash \& Kumar [8]. 
Table 1. Variables and Indicators of Kampung Jawi Sustainability.

\begin{tabular}{|c|c|c|}
\hline Aspect & Variabel & Indicator \\
\hline \multirow[t]{3}{*}{ Economic } & Employment Quality & $\begin{array}{l}\text { - Income } \\
\text { - Working time }\end{array}$ \\
\hline & Economic Viability & $\begin{array}{l}\text { - Local economic diversity } \\
\text { - Community economic resilience }\end{array}$ \\
\hline & Local Prosperity & $\begin{array}{l}\text { - Local product diversity } \\
\text { - Local product marketing }\end{array}$ \\
\hline \multirow[t]{4}{*}{ Socio-Cultural } & Visitor Fulfillment & $\begin{array}{l}\text { - Host-guest interaction } \\
\text { - Quality of cultural education }\end{array}$ \\
\hline & Local Control & $\begin{array}{l}\text { - Local people's participation } \\
\text { - Local people's knowledge about sustainable } \\
\text { tourism }\end{array}$ \\
\hline & Community Wellbeing & $\begin{array}{l}\text { Local cultural contribution to tourism } \\
\text { development }\end{array}$ \\
\hline & Cultural Richness & $\begin{array}{l}\text { - Availability of funds and facilities to } \\
\text { maintenance cultural resources } \\
\text { - Intensity of cultural activities } \\
\text { - Generation for cultural preservation }\end{array}$ \\
\hline \multirow[t]{2}{*}{ Environmental } & Physical Integrity & $\begin{array}{l}\text { - Suitability of facilities to tourism activities } \\
\text { - Availability of new normal facilities }\end{array}$ \\
\hline & Environmental Purity & Action to reduce pollution \\
\hline
\end{tabular}

The total score of sustainability is obtained from the average score of all sustainability aspects. The total score represents the level of sustainability of Kampung Jawi as a tourism destination. The level of sustainability is categorized into low, medium, and high based on the range of values in Table 2 .

Table 2. Levels of Sustainability Tourism.

\begin{tabular}{|c|c|l|}
\hline $\begin{array}{c}\text { Total } \\
\text { Score }\end{array}$ & $\begin{array}{c}\text { Sustainability } \\
\text { Level }\end{array}$ & \multicolumn{1}{c|}{ Criteria } \\
\hline $94-157$ & Low & $\begin{array}{l}\text { Kampung Jawi as a tourist destination has not been able to prosper } \\
\text { the community, does not provide long-term economic benefits, does } \\
\text { not help the preservation of local cultural values, and harms on the } \\
\text { surrounding environment [12, 13]. }\end{array}$ \\
\hline $158-219$ & Medium & $\begin{array}{l}\text { Kampung Jawi as a tourist destination can improve community } \\
\text { welfare, provide economic benefits, contribute to the preservation of } \\
\text { local cultural values, and the negative impact on the environment can } \\
\text { still be tolerated. However, further improvements and optimization } \\
\text { are still needed in the future, both from economic, social, and } \\
\text { environmental aspects [12, 13]. }\end{array}$ \\
\hline $220-282$ & High & $\begin{array}{l}\text { Kampung Jawi as a tourist destination has succeeded in improving } \\
\text { the welfare of the community, providing long-term economic } \\
\text { benefits, supporting the preservation of local cultural values, and } \\
\text { preserve surrounding environment [12, 13]. }\end{array}$ \\
\hline
\end{tabular}

\section{Result and Discussion}




\subsection{Analysis of Tourism Components in Kampung Jawi}

The Covid-19 pandemic has affected tourism activities in Kampung Jawi. There have been changes in several tourism components, including reduced tourist attractions, reduced operating hours, improved cleanliness facilities, and others.

\subsubsection{Attraction}

Cultural tourism attractions in Kampung Jawi can be grouped into 4 types: Traditional culinary, Javanese culture education, art performances, and Memetri Kampung Jawi tradition. Each group of attractions consists of several cultural and artistic activities, with a total of 11 activities that tourists can enjoy. Tourists can visit Kampung Jawi from morning to night in one tour package. Various cultural activities in Kampung Jawi become a core tourist experience that can attract tourists and improve the quality of the destination [13]. However, during the Covid-19 pandemic, tourists can only enjoy traditional culinary at Angkringan Pinggir Kali. Other tourist attractions had to be stopped indefinitely. This is to prevent activities that cause crowds and reduce the risk of spreading the Covid-19 virus. The pandemic has significantly restricted tourism and cultural arts activities, this condition can threaten the resilience of creative economy and culture [14].
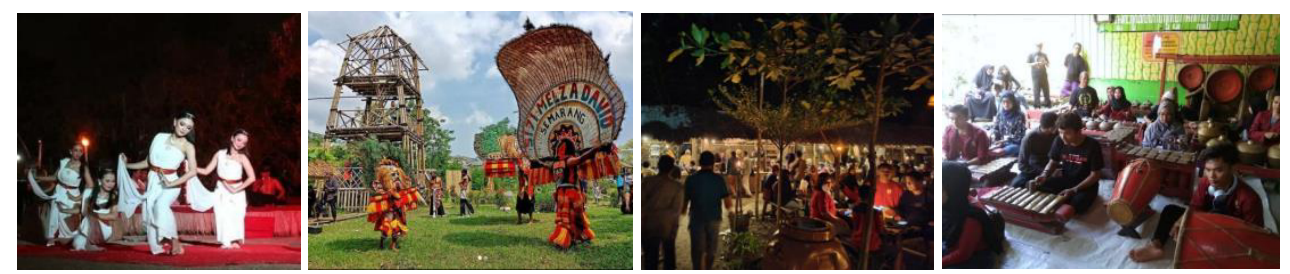

Fig. 2. Tourist Attractions in Kampung Jawi Before Covid-19 Pandemic.

\subsubsection{Amenities}

Amenities in a tourist destination include accommodation, facilities, and infrastructure needed by tourists during a tour [6]. Kampung Jawi has not yet provided lodging accommodation for tourists, big-scale resturants, and souvenir shop. Some of facilities that have been provided are a guest reception area, public toilets, a mosque, a parking area, and small-scale restaurants. During the Covid-19 pandemic, there were additional cleanliness and health facilities as an adaptation of new normal habits in tourist areas by following the policy of the Semarang City Government. There are a washbasin, a temperature gauge, a poster about health protocols, and a queue barrier. Currently, there are still many things that need to be added to support the new normal habit in Kampung Jawi.

\subsubsection{Accessibility}

Spatial accessibility is very important to support the development of tourism and attractions [15]. Access to Kampung Jawi is quite easy and can be reached using various types of vehicles. Most of the environmental pavements in Kampung Jawi use paving blocks in good condition. The road width in Kampung Jawi ranges from 2.5 to 3 meters, so it can only be passed by small vehicles such as motorbikes, cars, and minibusses. Vehicles that carrying passengers on a large scale, such as tourist buses, cannot go through the existing roads in Kampung Jawi. Some signages are directing to Kampung Jawi which is installed in a strategic location and can be seen clearly. 


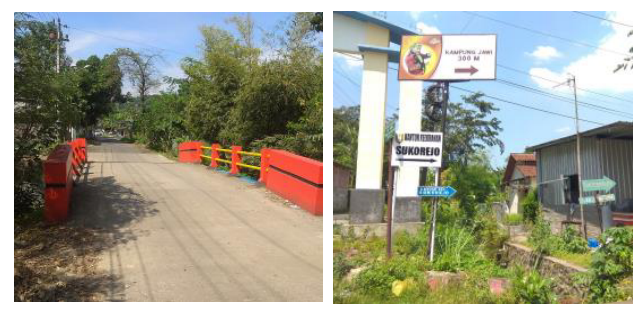

Fig. 3. Accessibility Support Facilities to the Kampung Jawi Tourist Area.

\subsubsection{Ancillary}

Kampung Jawi tourism is managed by a tourism awareness group called Pokdarwis Kampung Jawi. The main role of Pokdarwis Kampung Jawi is to manage the tourism development of Kampung Jawi, including planning, implementing, monitoring, and evaluating activities. Members of the Pokdarwis Kampung Jawi are 70 local people of Kampung Jawi. Pokdarwis Kampung Jawi participated in trainings organized by the government. The trainings that were attended included training in tourism promotion, tourism management, tourism innovation, and others. During the Covid-19 pandemic, Pokdarwis Kampung Jawi received a lot of direction on health protocols that must be implemented in tourist areas. Kampung Jawi was also strictly monitored by the Culture and Tourism Office during the pandemic.

\subsection{Analysis of Kampung Jawi Sustainability as Tourist Destination During Covid-19 Pandemic}

Analysis of Kampung Jawi's sustainability as a tourist destination during the Covid-19 pandemic was divided based on economic, socio-cultural, and environmental aspects. Each aspect is measured using the scoring from questionnaire results. The questionnaire was filled by local people of Kampung Jawi as respondents. Based on the results of the scoring, the overall level of Kampung Jawi sustainability as a tourist destination during the pandemic is in the "Medium" category. Table 3 shows the scoring results of the sustainability level of Kampung Jawi.

Table 3. The Scoring Result of Sustainability Aspects in Kampung Jawi.

\begin{tabular}{|c|c|c|c|c|c|}
\hline \multirow{2}{*}{ Question Item } & \multicolumn{3}{|c|}{ Frequency } & \multirow{2}{*}{ Score } & \multirow{2}{*}{ Aspect Score } \\
\hline & 1 & 2 & 3 & & \\
\hline \multicolumn{6}{|l|}{ Economic Aspect } \\
\hline $\begin{array}{l}\text { During this pandemic, can sellers work every day to } \\
\text { support tourist activities? }\end{array}$ & 5 & 8 & 81 & 264 & \multirow{6}{*}{$\begin{array}{c}207 \\
\text { (Medium } \\
\text { Sustainability) }\end{array}$} \\
\hline $\begin{array}{l}\text { Has the Covid-19 pandemic led to restricted working } \\
\text { hours and visitor numbers? }\end{array}$ & 72 & 16 & 6 & 122 & \\
\hline $\begin{array}{l}\text { Do tourism activities encourage the development of } \\
\text { various types of local economic enterprises? }\end{array}$ & 8 & 28 & 58 & 238 & \\
\hline $\begin{array}{l}\text { Do you understand the strategy for maintaining } \\
\text { economic sustainability in a pandemic situation? }\end{array}$ & 20 & 48 & 26 & 194 & \\
\hline $\begin{array}{l}\text { Are the products offered more diverse due to tourist } \\
\text { activities? }\end{array}$ & 5 & 46 & 43 & 226 & \\
\hline $\begin{array}{l}\text { Are local products difficult to market because of the } \\
\text { pandemic? }\end{array}$ & 7 & 73 & 14 & 195 & \\
\hline
\end{tabular}




\begin{tabular}{|c|c|c|c|c|c|}
\hline \multirow{2}{*}{ Question Item } & \multicolumn{3}{|c|}{ Frequency } & \multirow{2}{*}{ Score } & \multirow{2}{*}{ Aspect Score } \\
\hline & 1 & 2 & 3 & & \\
\hline \multicolumn{6}{|l|}{ Socio-cultural Aspect } \\
\hline $\begin{array}{l}\text { How was the interaction between local people and } \\
\text { tourists during the Covid-19 pandemic? }\end{array}$ & 6 & 16 & 72 & 254 & \multirow{11}{*}{$\begin{array}{c}190 \\
\text { (Medium } \\
\text { Sustainability) }\end{array}$} \\
\hline $\begin{array}{l}\text { How was the implementation of cultural education } \\
\text { activities for tourists during the pandemic? }\end{array}$ & 52 & 25 & 17 & 153 & \\
\hline $\begin{array}{l}\text { Are you participating in the tourism activities of } \\
\text { Kampung Jawi? }\end{array}$ & 20 & 57 & 17 & 185 & \\
\hline Do you know about sustainable tourism? & 31 & 48 & 15 & 172 & \\
\hline $\begin{array}{l}\text { Until now, can the existing culture in Kampung Jawi } \\
\text { attract tourists to come? }\end{array}$ & 2 & 48 & 44 & 230 & \\
\hline $\begin{array}{l}\text { Do cultural preservation activities supported by } \\
\text { sufficient funds? }\end{array}$ & 10 & 75 & 9 & 187 & \\
\hline $\begin{array}{l}\text { Do cultural preservation activities supported by } \\
\text { adequate facilities or facilities? }\end{array}$ & 6 & 59 & 29 & 211 & \\
\hline $\begin{array}{l}\text { Do the younger generations of Kampung Jawi have } \\
\text { cultural knowledge and skills? }\end{array}$ & 5 & 60 & 29 & 212 & \\
\hline $\begin{array}{l}\text { How was the intensity of cultural practices during the } \\
\text { pandemic? }\end{array}$ & 28 & 58 & 8 & 168 & \\
\hline $\begin{array}{l}\text { How was the intensity of the implementation of } \\
\text { community forum activities during the pandemic? }\end{array}$ & 29 & 52 & 13 & 172 & \\
\hline $\begin{array}{l}\text { Was the Memetri Kampung Jawi tradition held during } \\
\text { the pandemic? }\end{array}$ & 50 & 32 & 12 & 150 & \\
\hline \multicolumn{6}{|l|}{ Environmental Aspect } \\
\hline $\begin{array}{l}\text { Are the tourism facilities suitable for what community } \\
\text { and tourists needed? }\end{array}$ & 9 & 77 & 8 & 187 & \multirow{3}{*}{$\begin{array}{c}221 \\
\text { (High } \\
\text { Sustainability) }\end{array}$} \\
\hline $\begin{array}{l}\text { How is the availability of cleanliness and health } \\
\text { facilities in the tourist area of Kampung Jawi? }\end{array}$ & 0 & 63 & 31 & 219 & \\
\hline $\begin{array}{l}\text { Do tourism activities have a negative impact on the } \\
\text { environment? }\end{array}$ & 2 & 22 & 70 & 256 & \\
\hline \multicolumn{5}{|l|}{ Sustainability Score (Average) } & $\begin{array}{c}206 \\
\text { (Medium } \\
\text { Sustainability) }\end{array}$ \\
\hline
\end{tabular}

Based on thescoring result, the environmental aspect has the highest score. More than $50 \%$ of respondents assessed that tourism support facilities and health protocol facilities in Kampung Jawi are already available, but still need to be improved both in quality and quantity. $74 \%$ of respondents assessed that tourism activities do not cause environmental degradation, there are various efforts to prevent environmental degradation. Meanwhile, the socio-cultural aspect has the lowest score. More than $50 \%$ of responden chose a scale of "2" on each question item which indicates that socio-cultural activities in Kampung Jawi are still held and organized but not optimal.

\subsubsection{Economic Aspect}

According to Asmelash and Kumar [8], economic sustainability is measured by employment quality, economic viability, and local prosperity. The income of the people who work at Angkringan Pinggir Kali has decreased by more than $50 \%$. This is due to the limited operating hours and the number of visitors. The only attraction that is still open is Angkringan Pinggir Kali to empower the community's economy as well as to keep tourism activities 
running. The operational hours of Angkringan Pinggir Kali before the pandemic start at 16.00-00.00 WIB. But during the pandemic, it becomes 17.00-22.00 WIB. Meanwhile, in normal conditions, the number of visitors could reach $1.000-1.500$ people every day. But during the pandemic period, it was only 200-300 people a day.

In the economic sector, tourism provides a high multiplier effect, so if this sector falls it will cause a large domino effect, for those who are directly or indirectly involved [16]. The Covid-19 pandemic caused many tourism actors have be cut off temporarily or permanently [17]. People who work in the tourism sector such as tour guides, parking attendants, transportation services, and so on, get uncertain income even lose a job. Most of the local community are high school graduates and not equipped with sufficient knowledge about economic resilience. In this case, the government has an important role in restoring the tourism economy during the pandemic through the provision of stimulus in the form of funds, planning for the recovery of the tourism sector, and directing the local community [18].

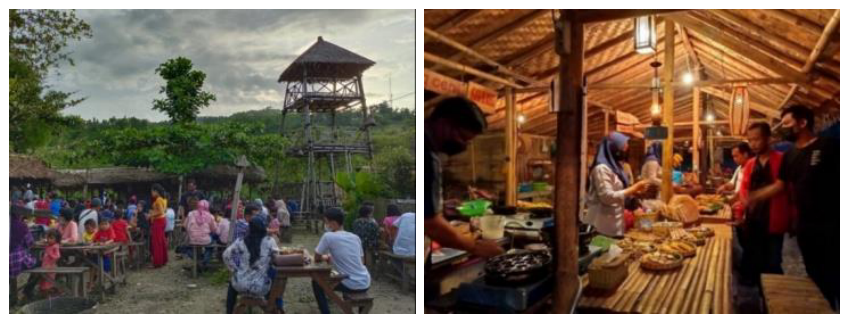

Fig. 4. The situation in Angkringan Pinggir Kali (the only attraction open during the Covid-19 pandemic).

From the economic viability and local prosperity aspect, tourism development in Kampung Jawi encourages the development of various local economic businesses and local economic products. Small to medium-scale entrepreneurs generally see tourism activities as benefiting their business and improving marketing [19]. Tourism activities make the products more easily recognized by the wider community. In addition, entrepreneurs also have the motivation to continue to develop and innovate their products. However, during this pandemic, product marketing has become more difficult as fewer people visit Kampung Jawi. Entrepreneurs do not have sufficient knowledge of strategies for economic sustainability in times of pandemics. To realize economic sustainability, it is necessary to develop human resources through training, mentoring, and empowerment. According to Azari et al. [17], one of the most important things to recover from crisis and disaster is human resource development.

During the Covid-19 pandemic economic activity in Kampung Jawi was still running and providing economic benefits to the community despite there being problems, challenges, and restrictions. Based on research from Uzun \& Somuncu [12], the level of sustainability of tourist destinations in the economic aspect is included in the medium category if the community does not get many economic benefits, uncertainty job, and the level of income is low. Economic activity in Kampung Jawi still continues with various restrictions. However, the economic conditions tend to be uncertain, and long-term economic viability is unclear.

\subsubsection{Socio-Cultural Aspect}

From the three aspects of sustainability, the socio-cultural aspect has the lowest score. Kampung Jawi community assessed that the socio-cultural aspect is the most affected aspect by the Covid-19 pandemic. According to Asmelash and Kumar [8], socio-cultural sustainability is measured by visitor fulfillment, cultural richness, local control, and community wellbeing. During the Covid-19 pandemic, host-guest interactions were still well 
established by implementing health protocols. However, tourists cannot learn about local culture because cultural education was stopped during the pandemic. Cultural events can benefit the promotion of cultural heritage and maximize social interaction between local communities and tourists [17]. In this pandemic condition, tourist satisfaction can decrease because they cannot enjoy various cultural activities or events

Initially, cultural activities in Kampung Jawi included cultural practices, performing arts, and traditions that were held every day. During the Covid-19 pandemic, these activities had to be stopped and postponed. The COVID-19 pandemic has a major impact on tourism and culture, with restrictions on movement and travel, outdoor activities, and large gatherings [14]. Traditional musical instruments, performance costumes, and other art instruments are neglected because they are rarely used. Meanwhile, resources include funds and facilities to support cultural preservation in Kampung Jawi are limited. Funds come from nongovernmental organizations or communities, supporting facilities such as art buildings and performances are not yet available.
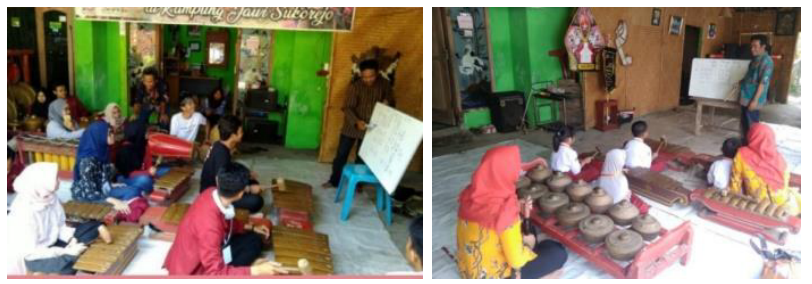

Fig. 5. Cultural practice and education activities before the Covid-19 pandemic.
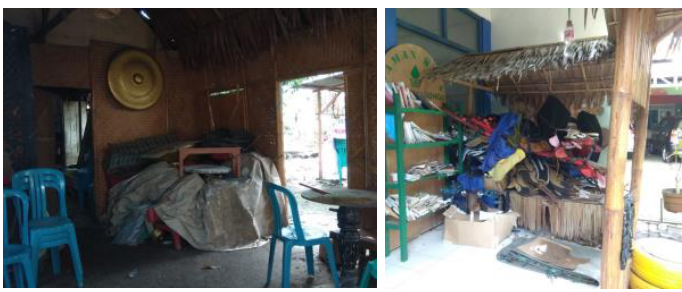

Fig. 6. Cultural instruments were neglected during the Covid-19 pandemic.

Community wellbeing in the socio-cultural aspects related to how local culture contributes to tourism development. In pandemic conditions, the local culture of Kampung Jawi still contributes to cultural activities. Even though out of a total of 11 cultural attractions, only 1 opened, tourists are still interested in coming to Kampung Jawi. Tourist attractions that still elevate cultural values are important to strengthen the cultural pillars in sustainable tourism [17]. Local control can be seen from community activities in managing Kampung Jawi, for example, community forums which are held regularly every week and every month. However. during a pandemic, the intensity of community forums is reduced. The forum is only held whenever there is an urgent need, such as when there is damage and additional facilities.

Local culture is a strong attraction for tourism development, where tourism development is highly dependent on cultural, ethnic heritage, and festival events [20]. For the people of Kampung Jawi, socio-cultural activities are images, characteristics, and the main attraction of tourism. The Covid-19 pandemic can threaten the sustainability of Kampung Jawi as a tourist destination and can relieve the identity of Kampung Jawi as a cultural tourism village in Semarang City. Socio-cultural sustainability is also threatened by internal challenges like the lack of public knowledge about sustainable tourism and limited resources for tourism and cultural development. Kampung Jawi condition according to Arifiani \& Mussadun [11] and Uzun \& Somuncu [12], the medium level of socio-cultural sustainability indicates that 
tourism activities can support cultural preservation and respect the local culture. But the implementation is not supported by adequate resources like manpower, facilities, and funds.

\subsubsection{Environmental Aspect}

Based on the results of scoring and community assessment, the sustainability of Kampung Jawi from an environmental aspect is included in the "High" category. According to Arifiani \& Mussadun [11] and Asmelash \& Kumar [8], the level of environmental sustainability includes in the "high" category when tourism development activities do not have a negative impact on the environment and tourism supporting facilities are well integrated into the environment. Environmental sustainability is assessed based on physical integrity and environmental purity.

Based on physical integrity, the community assessed that the facilities in Kampung Jawi are suitable with what is needed by the community and tourists. Facilities that need to be improved are facilities to support cultural preservation, such as art buildings, cultural galleries, and others. In the conditions of the Covid-19 pandemic, the Kampung Jawi tourist area was equipped with health and cleanliness facilities according to the new normal habit protocol. One of the important things to improve tourist destination's quality is hygiene, including cleanliness in tourist areas and the availability of cleaning facilities [13]. There is a washbasin, temperature gauge, queue divider, and health protocol posters. However, cleanliness and health facilities are only available in the Angkringan Pinggir Kali area. Therefore, the cleanliness and health facilities still need to be improved. The pandemic encourages tourists to be more aware of safety and cleanliness [21].

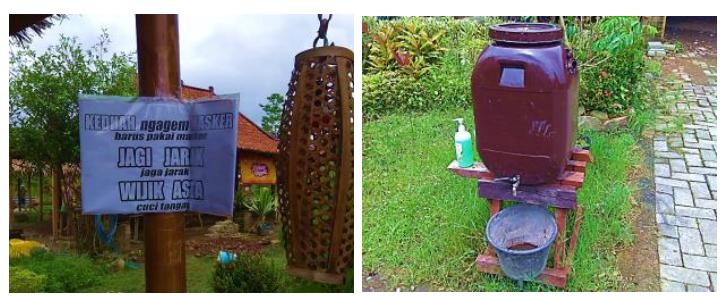

Fig. 7. Cleanliness and health facilities that provided in the Kampung Jawi tourist area.

Meanwhile, one of the positive impacts of the Covid-19 pandemic is the low level of pollution and environmental degradation due to restrictions on human activities [16]. Air quality and water quality improve so that the quality of public health also improves. Besides that, people are also really concerned about the cleanliness, beauty, and preservation of Kampung Jawi. There are various efforts to prevent environmental damage such as waste recycling systems, waste banks, reforestation, reducing consumption of plastic waste, and others.

\section{Conclusion}

Based on this research, the overall score of Kampung Jawi sustainability as a tourist destination is 206 and the level of sustainability is "Medium". From the three aspects of sustainability, the socio-cultural aspect has the lowest score. The socio-cultural aspect score is 190 and the level of sustainability is "Medium". According to the community assessment, the socio-cultural aspect is the most affected aspect by the Covid-19 pandemic. Meanwhile, the environmental aspect has the highest score. The environmental aspect score is 221 and 
the level of sustainability is "High". Cleanliness and health facilities according to health protocols have been provided but have to improve. Tourism activities in Kampung Jawi still provide economic benefits, support cultural preservation, and maintain environmental purity even though there are many restrictions in the midst of a pandemic situation.

Cooperation between various stakeholders including the community, government, tourism awareness groups, and others to maintain the sustainability of Kampung Jawi is needed. Tourism stakeholders play an important role because the sustainability and resilience of a tourist destination depend on planning, anticipation, and responsiveness [22]. In the face of the Covid-19 pandemic, the tourism industry needs to build resilience to adapt to the changes that occur [23]. In addition, it is necessary to formulate appropriate plans and strategies for long-term tourism. The main thing that must be done is to change the behavior of the tourism industry actors [23]. To deal with a pandemic situation, the people of Kampung Jawi must apply a disciplined attitude and obey health protocols, be spirit, be resilient, and think positively. Based on findings of the sustainability of Kampung Jawi tourism during the Covid-19 pandemic, it is necessary to establish the resilience of the tourism industry. To realize tourism resilience, there are 4 things that must be considered, namely technological innovation, government response, increasing employee confidence, and local belongingness [18].

\section{Acknowledgment}

This research was financially supported by The Faculty of Engineering Diponegoro University, Indonesia through Strategic Research Grand 2021. The authors would like to thank the Kampung Jawi community who gave information and support in this research.

\section{References}

1. L. Arlym and D. Hermon, "Strategy of ecotourism development in Pariaman City," IOP Conf. Ser. Earth Environ. Sci., Vol. 314, no. 1, 2019, doi: 10.1088/17551315/314/1/012039.

2. S. R. Sari, E. P. Hendro, and M. F. Hilmy, "Maintaining sustainability of tourism kampong. The case of kampong pelangi in semarang," J. Environ. Manag. Tour., Vol. 11, no. 2, pp. 331-340, 2020, doi: 10.14505/jemt.v11.2(42).11.

3. Pemerintah Kota Semarang, "Semarang Satu Data: Jumlah Kunjungan Wisatawan," semarsatata.semarangkota.go.id, 2020. https://semarsatata.semarangkota.go.id/data/list/4 (accessed Feb. 24, 2021).

4. U. D. E. Noviyanti, N. E. Suriyani, A. Umardiono, N. E. Suharno, and S. E. N. Hidayati, "Development of kampung tourism Lawas Maspati as the prominent destination in Surabaya, Indonesia," African J. Hosp. Tour. Leis., Vol. 9, no. 2, pp. $1-15,2020$.

5. M. A. Yusuf, R. R. Ari, R. Kisnarini, D. Septanti, and H. R. Santosa, "Planning for sustainable tourism. case study: kampung of cookies, Surabaya, Indonesia," $J$. Settlements Spat. Plan., Vol. 10, no. 1, pp. 49-60, 2019, doi: 10.24193/JSSP.2019.1.05.

6. Isdarmanto, Dasar-Dasar Kepariwisataan dan Pengelolaan Destinasi Pariwisata. 2017.

7. S. Purnomo, E. S. Rahayu, A. L. Riani, S. Suminah, and U. Udin, "Empowerment model for sustainable tourism village in an emerging country," J. Asian Financ. Econ. Bus., Vol. 7, no. 2, pp. 261-270, 2020, doi: 10.13106/jafeb.2020.vol7.no2.261.

8. A. G. Asmelash and S. Kumar, "Assessing progress of tourism sustainability: Developing and validating sustainability indicators," Tour. Manag., Vol. 71, pp. 6783, 2019, doi: 10.1016/j.tourman.2018.09.020. 
9. Pemerintah Kota "Kampung Tematik," http://gerbanghebat.semarangkota.go.id/home/hal-tematik/1. (2017)

10 Sugiyono, Metode Penelitian Kuantitatif, Kualitatif dan R\&D. Bandung: Alfabeta, (2015)

11. N. A. Arifiani and M. Mussadun, "Studi persepsi masyarakat terhadap tingkat keberlanjutan wilayah pesisir Kecamatan Sarang," J. Wil. dan Lingkung., Vol. 4, no. 3, pp. 171-186, doi: 10.14710/jwl.4.3.171-186. (2016)

12. F. V. Uzun and M. Somuncu, "Evaluation of the sustainability of tourism in Ihlara Valley and suggestions," Eur. J. Sustain. Dev., Vol. 4, no. 2, pp. 165-174, doi: 10.14207/ejsd.2015.v4n2p165. (2015)

13. S. D. Rajaratnam, V. Nair, S. Pahlevan Sharif, and U. T. Munikrishnan, "Destination quality and tourists' behavioural intentions: rural tourist destinations in Malaysia," Worldw. Hosp. Tour. Themes, Vol. 7, no. 5, pp. 463-472, doi: 10.1108/WHATT-062015-0026. (2015)

14. T. Flew and K. Kirkwood, "The impact of COVID-19 on cultural tourism: art, culture and communication in four regional sites of Queensland, Australia," Media Int. Aust., Vol. 178, no. 1, pp. 16-20, doi: 10.1177/1329878X20952529. (2021)

15. Y. A. Wibowo and L. Ronggowulan, "Potential analysis and community-based sustainable tourism development strategy (a case of kampung menjing, sukoharjo regency, central java, indonesia)," IOP Conf. Ser. Earth Environ. Sci., Vol. 683, no. 1, pp. 1-13, doi: 10.1088/1755-1315/683/1/012112. (2021)

16. L. Moreno-Luna, R. Robina-Ramírez, M. S. O. Sánchez, and J. Castro-Serrano, "Tourism and sustainability in times of covid-19: The case of Spain," Int. J. Environ. Res. Public Health, Vol. 18, no. 4, pp. 1-22, doi: 10.3390/ijerph18041859. (2021)

17. D. Azhari, A. Rosyidie, S. Sagala, A. Ramadhani, and J. F. Karistie, "Achieving sustainable and resilient tourism: Lessons learned from Pandeglang tourism sector recovery," IOP Conf. Ser. Earth Environ. Sci., Vol. 704, no. 1, pp. 1-12, doi: 10.1088/1755-1315/704/1/012007.(2021)

18. G. D. Sharma, A. Thomas, and J. Paul, "Reviving tourism industry post-COVID-19: A resilience-based framework" Tour. Manag. Perspect., Vol. 37, no. December 2020, p. 100786, doi: 10.1016/j.tmp.2020.100786. (2021)

19. M. Št’Astná, A. Vaishar, J. Brychta, K. Tuzová, J. Zloch, and V. Stodolová, “Cultural tourism as a driver of rural development. Case study: Southern Moravia," Sustain., Vol. 12, no. 21, pp. 1-16, doi: 10.3390/su12219064.(2020)

20. P. Kunasekaran, S. S. Gill, S. Ramachandran, A. Shuib, T. Baum, and S. H. M. Afandi, "Measuring sustainable indigenous tourism indicators: A case of Mah Meri ethnic group in Carey Island, Malaysia," Sustain., Vol. 9, no. 7, doi: 10.3390/su9071256.(2017)

21. S. S. Wachyuni and D. A. Kusumaningrum, "The Effect of COVID-19 Pandemic: How are the Future Tourist Behavior?," J. Educ. Soc. Behav. Sci., Vol. 33, no. 4, pp. 67-76, doi: 10.9734/jesbs/2020/v33i430219.(2020)

22. D. M. Lemy, A. Pramezwary, F. Teguh, and R. Pramono, "How sustainable is our destination? A snap-shot from the first Indonesia sustainable tourism destination award," African J. Hosp. Tour. Leis., Vol. 8, no. 1, pp. 1-17, (2019)

23. Y. Kristiana, R. Pramono, and R. Brian, "Adaptation Strategy of Tourism Industry Stakeholders During the COVID-19 Pandemic: A Case Study in Indonesia," J. Asian Financ. Econ. Bus., Vol. 8, no. 4, pp. 0213-0223, 2021, doi: 10.13106/jafeb. vol8.no4.0213.(2021) 